\title{
AVALIAÇÃO DO DESEMPENHO DE SISTEMA DE REÚSO DE ÁGUA DE UMA EDIFICAÇÃO UNIFAMILIAR EM GOIÂNIA-GO
}

\author{
Larissa Paranhos Nirenberg ${ }^{1}$, Ricardo Prado Abreu Reis ${ }^{2}$ \\ Escola de Engenharia Civil da Universidade Federal de Goiás - Goiânia - GO - Brasil
}

Recebido em 1 de janeiro de 2010; recebido para revisão em 25 de janeiro de 2010; aceito em 10 de fevereiro de 2010; disponível on-line em 12 de fevereiro de 2010

\section{PALAVRAS CHAVES: \\ Reúso de água cinza; \\ Tratamento de efluente doméstico; \\ Conservação de água; \\ Sistemas hidráulicos sanitários prediais.}

\begin{abstract}
RESUMO: A desordenada gestão da oferta e demanda de água nas edificações requer soluções sustentáveis, com bases metodológicas apropriadas, e, dentre estas se destacam as técnicas de conservação de água, tais como a utilização de fontes alternativas de suprimento de água em sistemas prediais. O reúso de águas cinza para fins não potáveis consolida este objetivo, e o trabalho realizado visou apresentar a concepção de um sistema domiciliar de reúso de efluentes provenientes de descargas de chuveiros, lavatórios, tanque e máquina de lavar roupas implantado em uma residência unifamiliar no município de Goiânia, GO. A avaliação do desempenho do sistema, constituído de um tanque de sedimentação, um filtro de brita e areia com recirculação e desinfecção por UV consistiu o objetivo desta pesquisa. A concepção e implantação do sistema, bem como o monitoramento das variáveis de operação quantitativas e qualitativas do efluente, antes e após o tratamento caracterizaram a metodologia. Os resultados obtidos foram úteis no melhor conhecimento das unidades do sistema, assim como a comparação dos resultados de qualidade do afluente e efluente, os quais demonstraram a evolução do sistema de tratamento por filtração, a importância da maturação dos filtros na melhora da qualidade da água tratada. Percebeu-se, também, o potencial de conservação de água, a viabilidade de implantação do sistema, e o elevado período de retorno.
\end{abstract}

\footnotetext{
* Contato com os autores: Tel.: +55 6232096084

1 e-mail : rpareis@gmail.com (R.P.A.Reis)

${ }^{2}$ e-mail : Inirenberg@hotmail.com (L.P.Nirenberg)
}

\section{ISSN: 0000-0000}

(C) 2010 REEC - Todos os direitos reservados. doi: $00.0000 /$ r.eleengcivil.2010.01.010

\section{INTRODUÇÃO}

Uma das ações previstas em um plano de conservação de água em edificações - PCA consiste na adoção de fontes alternativas de suprimento de água (OLIVEIRA, 1999). Dentre as fontes alternativas, podem ser citados os sistemas prediais de reúso de água, os quais possibilitam utilizar uma parcela da água por mais de uma vez em uma ou mais atividades. Os sistemas prediais de reúso de água envolvem etapas de coleta e tratamento de esgoto sanitário, seguida por armazenamento e distribuição. O efluente utilizado pode ser o secundário, proveniente de descargas de chuveiros, lavatórios, tanques e máquinas de lavar roupas, também denominado águas cinza, ou o efluente primário, constituído pela mistura dos efluentes citados anteriormente mais os originados nas bacias sanitárias e pias de cozinha, também denominados águas negras. 
A definição da unidade de tratamento depende das características do efluente coletado e da qualidade da água de reúso necessária para um fim pré-definido (OLIVEIRA et al., 2007).

Apesar da falta da consolidação de diretrizes e políticas públicas nacionais que definam critérios de concepção de sistemas domésticos de reúso de água, o

desenvolvimento de estudos, em

situações reais, que permitam avaliar parâmetros como a caracterização do efluente a ser tratado, a qualidade da água após tratamento, vazões de descarga, operacionalidade, além de aspectos de viabilidade e segurança são de extrema importância para o aprimoramento das técnicas utilizadas nesses sistemas.

Portanto, este trabalho teve como objetivo avaliar o desempenho de um sistema de reúso de águas provenientes de chuveiros, lavatórios e área de serviço implantado em uma residência unifamiliar no município de Goiânia - GO. O sistema encontra-se atualmente desativado, e sua unidade de tratamento consiste de um tanque de sedimentação, seguido por filtro biológico constituído por duas camadas, sendo uma de brita e outra de areia, por onde circula o efluente, e por último um sistema de desinfecção por ultravioleta.

Com base neste sistema, pretendeu-se:

1. caracterizar físico-química e biologicamente a água de reúso pré e pós-tratamento;

2. avaliar a concepção do sistema de reúso;

3. estudar seu potencial de conservação de água;

4. avaliar seu custo de implantação; e

5. avaliar os procedimentos de manutenção e operação.

\section{MATERIAIS E MÉTODOS}

O estudo foi realizado por meio do monitoramento e avaliação da operação de um sistema de reúso de água experimental, submetido a condições reais de funcionamento em uma residência unifamiliar na cidade de Goiânia - GO.

Para avaliação de desempenho da unidade de tratamento do sistema, constituído por um filtro biológico de brita e areia, foram coletadas amostras pré e pós-tratamento, com intervalos quinzenais. As amostras foram encaminhadas para o laboratório da ETE Goiânia (ETE Dr. Hélio Seixo de Britto) da SANEAGO para avaliação dos parâmetros: DBO, oxigênio dissolvido, DQO, pH, turbidez, cor, sólidos sedimentáveis, sólidos totais, sólidos totais voláteis, sólidos totais fixos, sólidos suspensos, nitrogênio amoniacal total, óleos e graxas, alcalinidade total, nitrogênio kjeldahl, acidez, sulfeto, sulfeto total, surfactantes, ferro dissolvido, fósforo, condutividade e coliformes termotolerantes.

O monitoramento do sistema de tratamento de águas cinza foi realizado por um período de cinco (5) meses, supondo ser necessário aproximadamente 2 (dois) meses para atingir a maturação dos filtros, que seria
- desenvolvimento completo dos microrganismos necessários ao tratamento.

Os parâmetros avaliados foram comparados com os limites sugeridos pelas seguintes legislações: NBR 13969 (1997), U. S. EPA (Guidelines for Water Reuse, 2004), e o Guia de Conservação e Reúso da Água em Edificações (FIESP, 2005), visando, portanto, avaliar a eficiência dos sistemas de tratamento.

A vazão afluente ao sistema de reúso foi avaliada por meio do monitoramento da variação de nível d'água dentro do tanque de sedimentação, devido às atividades dos usuários da residência ao utilizarem o chuveiro, o lavatório e a área de serviço. O volume destinado ao sistema de tratamento foi medido por meio da diferença do nível d'água no tanque de sedimentação, o qual é a primeira unidade do mesmo, e que possui dimensões conhecidas, permitindo assim, o cálculo do volume por meio da Equação 1.

Onde:

$$
V=A b \times h
$$

Equação (1)

$\mathrm{V}=$ volume gerado $\left(\mathrm{m}^{3}\right)$

$A_{b}=$ área da seção do tanque de sedimentação $\left(m^{2}\right)$

$\mathrm{h}=$ altura do nível de água $(\mathrm{m})$

Por meio deste parâmetro, foi possível determinar qual o volume máximo de água de reúso que poderá ser utilizado diariamente para a irrigação de jardim, por exemplo.

A avaliação da concepção do sistema de reúso experimental foi feita por meio da observação da operação dos componentes do sistema implantado: captação, transporte, ramal de desligamento, tratamento, reservação, destinação, entre outros.

Por último, foi estudada a viabilidade do sistema que foi avaliada por meio do levantamento do custo de implantação, juntamente com operação e manutenção.

\section{REVISÃO BIBLIOGRÁFICA}

Os filtros biológicos consistem em tanques contendo leito de pedras, areia, ripas, material sintético ou outro material inerte que serve de suporte para aderência e desenvolvimento de microrganismos, os quais formam películas ou biofilmes na superfície, gerando alta retenção de biomassa no reator (ÁVILA, 2005).

O mecanismo do filtro biológico consiste na alimentação e percolação contínua do esgoto através do meio suporte. A contínua passagem dos esgotos nos interstícios promove o crescimento e aderência de massa biológica na superfície do meio suporte. Esta aderência é favorecida pela predominância de colônias gelatinosas, mantendo suficiente período de contato da biomassa com o esgoto (JORDÃO E PESSÔA, 2005).

Em condições favoráveis ao processo, a massa biológica agregada ao meio suporte retém a matéria orgânica contida no esgoto, por meio de adsorção. A síntese de novas células promove o aumento da biomassa, prejudicando a passagem de oxigênio até as camadas internas, junto à superfície do meio suporte, 
onde o processo de oxidação ocorre anaerobicamente (SOBRINHO, 1997).

As condições favoráveis à adsorção da matéria orgânica pelas bactérias aeróbias ou anaeróbias, e a preservação de um ambiente úmido e ventilado, garantem a oxidação dos compostos, gerando gás carbônico $\left(\mathrm{CO}_{2}\right)$, ácidos nítrico $\left(\mathrm{HNO}_{3}\right)$ e sulfúrico $\left(\mathrm{H}_{2} \mathrm{SO}_{4}\right)$. As substâncias alcalinas contidas nos esgotos neutralizam os ácidos, transformando-os em sais solúveis em água (AISSE et al., 2001).

Os filtros biológicos podem ter várias formas, configurações e dimensões, desde que se obtenha fluxo bem distribuído pelo percolador, bem como o bom desempenho funcional. Estes podem ser verticais, com fluxo ascendente e descendente; ou horizontais, classificados em rápido e lento, e suas características constam no Quadro 01 (ÁVILA, 2005).

Os filtros biológicos também podem ser de baixa carga, onde a carga de DBO aplicada é baixa, com remoção deste variando de $15-40$ (mg/L), contribuindo para que o lodo saia parcialmente estabilizado devido ao consumo da matéria orgânica presente nas células das bactérias em seus processos metabólicos por causa da escassez de alimento. Estes têm eficiência comparável ao sistema de lodos ativados convencional, ocupam uma maior área e possuem uma menor capacidade de adaptação as variações do efluente (VON SPERLING, 2005).

O mesmo autor ainda ressalta outro filtro: o sistema de alta carga, o qual é menos eficiente que o sistema de filtros biológicos de baixa carga, com a remoção de taxa de DBO oscilando entre 30-60 (mg/L) o lodo não sai estabilizado. A área ocupada é menor e a carga de DBO aplicada é maior. Há uma recirculação do efluente para que mantenha os braços distribuidores funcionando durante a noite, quando a vazão é menor e, evitando assim que leito seque.
Com isto há também um novo contato das bactérias com a matéria orgânica melhorando a eficiência. Outra forma de aumentar a eficiência é colocando filtros biológicos em série. Há diferentes formas de combinar os filtros e a recirculação de efluentes.

A maturidade biológica do leito filtrante indicará o grau de desenvolvimento microbiológico por toda sua profundidade. Esta condição não é medida, mas é função do número de semanas de operação do filtro para determinadas condições da água bruta. As condições que mais afetam o tempo necessário para a maturidade do leito são a disponibilidade de nutrientes e a temperatura (BELLAMY et al., 1985).

Brito et al. (2005) enfatizam, também, que a remoção elevada de coliformes totais devido à maturação de filtros lentos biológicos, tanto de bactérias, vírus e cistos de Giardia, mas ressaltam o necessário entendimento dos processos de remoção destes patógenos no interior dos filtros, esclarecendo os mecanismos de retenção, tentando, assim, direcionar as decisões de projeto e operacionais, as quais ampliariam a segurança do processo.

Algumas características favoráveis dos processos anaeróbios, como elevados tempos de retenção de sólidos e baixos tempos de detenção hidráulica, os quais conferem aos mesmos um grande potencial para sua aplicabilidade em tratamento de águas residuárias de baixa concentração, constam no Quadro 02.

Para a definição de critérios de concepção e avaliação dos padrões de qualidade das águas em sistema prediais de reúso, destacam-se a USEPA (2004), a NBR 13969 (ABNT, 1997), e o Guia de Conservação e Reúso da Água em Edificações (FIESP, 2005).

A USEPA (2004) recomenda o uso de esgoto tratado em nível secundário para: irrigação de áreas verdes; culturas de vegetais consumidos após cozimento; em alguns locais de recarga de aqüíferos de água não

\begin{tabular}{|c|c|c|c|}
\hline & Fluxo Ascendente & Fluxo Descendente & Fluxo Horizontal \\
\hline Vantagens & $\begin{array}{l}\text { - Maior retenção de lodo em } \\
\text { excesso; } \\
\text { - Bom tempo de contato entre } \\
\text { o esgoto e o biofilme devido } \\
\text { aos lodos em sustentação } \\
\text { hidráulica; } \\
\text { - Propiciam alta eficiência e } \\
\text { baixa perda dos sólidos que } \\
\text { são arrastados no efluente; }\end{array}$ & $\begin{array}{l}\text { - Apresentam facilidade para } \\
\text { remoção de lodo em } \\
\text { excesso; Menor risco de } \\
\text { entupimento no leito; } \\
\text { - Podem receber esgotos } \\
\text { com maior concentração } \\
\text { de sólidos; } \\
\text { - Indicado para altas e baixas } \\
\text { cargas orgânicas; }\end{array}$ & $\begin{array}{l}\text { - Funciona com } \\
\text { características } \\
\text { intermediárias entre o } \\
\text { fluxo ascendente e o } \\
\text { descendente. }\end{array}$ \\
\hline Desvantagens & $\begin{array}{l}\text { - São mais indicados para } \\
\text { esgotos com baixa } \\
\text { concentração; } \\
\text { - Maiores riscos de } \\
\text { entupimento dos interstícios. }\end{array}$ & $\begin{array}{l}\text { - Os filtros com fluxo não } \\
\text { afogado apresentam baixa } \\
\text { eficiência. }\end{array}$ & $\begin{array}{l}\text { - Maior dificuldade na } \\
\text { distribuição do fluxo; } \\
\text { - Desempenho diferenciado } \\
\text { ao longo do leito; } \\
\text { - Concentração de lodo em } \\
\text { excesso mal distribuída; } \\
\text { - Remoção difícil do lodo; } \\
\text { - Deve ser usado com baixas } \\
\text { taxas de carga orgânica. }\end{array}$ \\
\hline
\end{tabular}

Fonte: ÁVILA (2005). 
Quadro 02: Vantagens e desvantagens dos processos anaeróbios.

\begin{tabular}{|c|c|}
\hline Vantagens & Desvantagens \\
\hline $\begin{array}{l}\text { - baixa produção de sólidos, cerca de } 5 \text { a } 10 \text { vezes } \\
\text { inferior à que ocorre nos processos aeróbios; } \\
\text { - baixo consumo de energia, usualmente associado } \\
\text { a uma elevatória de chegada, diminuindo os } \\
\text { custos operacionais; } \\
\text { - baixa demanda de área; } \\
\text { - baixos custos de implantação; } \\
\text { - produção de metano; } \\
\text { - possibilidade de preservação da biomassa, sem } \\
\text { - } \text { tolimentação do reator; } \\
\text { - aplicabilidade em pequena e grande escala; } \\
\text { - baixo consumo de nutrientes. }\end{array}$ & $\begin{array}{l}\text { - } \quad \text { as bactérias anaeróbias são susceptíveis à inibição } \\
\text { - } \quad \text { a por um grande número de compostos; } \\
\text { lodo de semeadura adaptado; } \\
\text { - } \quad \text { alguma forma de pós-tratamento é necessária; } \\
\text { - } \quad \text { a bioquímica e a microbiologia da digestão anaeróbia } \\
\text { - } \text { são complexas e precisam de mais estudos; } \\
\text { possibilidade de geração de maus odores, porém } \\
\text { - } \quad \text { pontroláveis; } \\
\text { - desagradilidade de geração de efluente com aspecto } \\
\text { remoção de nitrogênio, fósforo e patogênicos } \\
\text { insatisfatória. }\end{array}$ \\
\hline
\end{tabular}

Fonte: adaptado de CHERNICHARO (1997).

potável; em alguns locais de "habitat" silvestre; processos de resfriamento industrial; recomendações de tipos de tratamento; e estabelecimento de parâmetros de qualidade do efluente tratado.

A NBR 13969 - ABNT (1997) tem por objetivo oferecer alternativas de procedimentos técnicos para o projeto, construção e operação de unidades de tratamento complementar e disposição final dos efluentes líquidos de tanque séptico, dentro do sistema de tanque séptico para o tratamento local de esgotos. As alternativas aqui citadas devem ser selecionadas de acordo com as necessidades e condições locais onde é implantado o sistema de tratamento, não havendo restrições quanto à capacidade de tratamento das unidades. Conforme as necessidades locais, as alternativas citadas podem ser utilizadas complementarmente entre si, para atender ao maior rigor legal ou para efetiva proteção do manancial hídrico, a critério do órgão fiscalizador competente.

Tal norma determina, também, que quando houver usos múltiplos da água de reúso com qualidades distintas de água deve-se optar por reservações independentes e identificadas de acordo com a qualidade da água armazenada; o grau de tratamento requerido deve ser definido pelo uso mais restringente quanto à qualidade do efluente a ser tratado; o responsável pelo planejamento e projeto do sistema de reúso deve fornecer manuais de operação e especificações técnicas quanto ao sistema de tratamento, reservação e distribuição, além de treinamento adequado aos responsáveis pela operação do sistema (ABNT, 1997).

Dentre os parâmetros apresentados pela norma supracitada, ressaltam-se as seguintes taxas de remoção (\%) de poluentes para o filtro de areia e brita presentes no Quadro 03.
O Guia de Conservação e Reúso da Água em Edificações (FIESP, 2005) ressalta as principais atividades relacionadas ao reúso de água, que são: irrigação de áreas verdes e lavagem de pisos; descarga de bacias sanitárias; refrigeração de sistemas de ar condicionado; lavagem de veículos; lavagem de roupas; uso ornamental e na construção civil.

Quadro 03: Faixas prováveis de remoção dos poluentes, conforme o tipo de tratamento, consideradas em conjunto com o tanque séptico

\begin{tabular}{|l|c|}
\hline \multicolumn{1}{|c|}{ Parâmetro } & $\begin{array}{c}\text { Eficiência de remoção } \\
\text { Processo (Filtro de Areia) }\end{array}$ \\
\hline $\mathrm{DBO}_{5,20}$ & $50 \%-85 \%$ \\
\hline $\mathrm{DQO}$ & $40 \%-75 \%$ \\
\hline Sólidos Sedimentáveis & $100 \%$ \\
\hline Nitrogênio Amoniacal & $50 \%-80 \%$ \\
\hline Nitrato & $30 \%-70 \%$ \\
\hline Fosfato & $30 \%-70 \%$ \\
\hline Coliformes Fecais & $99,5 \%$ ou mais \\
\hline
\end{tabular}

Fonte: adaptado de NBR 13969, ABNT (1997).

O Guia também preconiza requisitos mínimos para águas com esta destinação, tais como: odor; segurança do usuário; cor; concentração de sais; água agressiva e preservação dos sistemas hidráulicosanitários.

A NBR 13969 - ABNT (1997), assim como o Guia de Conservação e Reúso da Água em Edificações (FIESP, 2005), classificam os parâmetros de qualidade de água a ser reutilizada, segundo as atividades de reúso, e sugere os tratamentos de efluentes requeridos, conforme o Quadro 04. 


\begin{tabular}{|c|c|c|c|c|}
\hline Classe & Uso Previsto & $\begin{array}{l}\text { Tratamento } \\
\text { Sugerido }\end{array}$ & Parâmetros de quali & de da água de reúso \\
\hline \multirow{5}{*}{ Classe 1} & \multirow{5}{*}{$\begin{array}{l}\text { Lavagem de carros e } \\
\text { outros usos que } \\
\text { requerem contato } \\
\text { direto do usuário com a } \\
\text { água com possível } \\
\text { aspiração de aerossóis } \\
\text { pelo operador, } \\
\text { incluindo chafarizes. }\end{array}$} & \multirow{5}{*}{$\begin{array}{l}\text { Tratamento aeróbio } \\
\text { (filtro aeróbio } \\
\text { submerso) seguido } \\
\text { por filtração } \\
\text { convencional (areia } \\
\text { e carvão ativado) e } \\
\text { cloração. }\end{array}$} & Turbidez & $<5 \mathrm{NTU}$ \\
\hline & & & Coliformes Fecais & $<200 \mathrm{NPM} / 100 \mathrm{~mL}$ \\
\hline & & & $\begin{array}{c}\text { Sólidos Dissolvidos } \\
\text { Totais }\end{array}$ & $<200 \mathrm{mg} / \mathrm{L}$ \\
\hline & & & $\mathrm{pH}$ & 6 a 8 \\
\hline & & & Cloro Residual & 0,5 a $1,5 \mathrm{mg} / \mathrm{L}$ \\
\hline \multirow[b]{3}{*}{ Classe 2} & \multirow{3}{*}{$\begin{array}{c}\text { Lavagem de pisos, } \\
\text { calçadas e irrigação de } \\
\text { jardins, manutenção } \\
\text { dos lagos e canais para } \\
\text { fins paisagísticos, exceto } \\
\text { chafarizes. }\end{array}$} & \multirow{3}{*}{$\begin{array}{c}\text { Tratamento } \\
\text { biológico aeróbio } \\
\text { (filtro aeróbio } \\
\text { submerso) seguido } \\
\text { por filtração de } \\
\text { areia e desinfecção. }\end{array}$} & Turbidez & $<5$ NTU \\
\hline & & & Coliformes Fecais & $<500 \mathrm{NPM} / 100 \mathrm{~mL}$ \\
\hline & & & Cloro Residual & $>0,5 \mathrm{mg} / \mathrm{L}$ \\
\hline \multirow[b]{2}{*}{ Classe 3} & \multirow{2}{*}{$\begin{array}{c}\text { Reúso em descargas de } \\
\text { bacias sanitárias. }\end{array}$} & \multirow{2}{*}{$\begin{array}{l}\text { Tratamento aeróbio } \\
\text { seguido por filtração } \\
\text { e desinfecção. }\end{array}$} & Turbidez & $<10$ NTU \\
\hline & & & Coliformes Fecais & $<500 \mathrm{NPM} / 100 \mathrm{~mL}$ \\
\hline \multirow[b]{2}{*}{ Classe 4} & \multirow[b]{2}{*}{$\begin{array}{l}\text { Reúso nos pomares, } \\
\text { forragens, pastos para } \\
\text { gado e outros cultivos, } \\
\text { através de escoamento } \\
\text { superficial ou sistema } \\
\text { de irrigação pontual. }\end{array}$} & \multirow[b]{2}{*}{$\begin{array}{l}\text { As aplicações devem } \\
\text { ser interrompidas } \\
\text { pelo menos } 10 \text { dias } \\
\text { antes da colheita. }\end{array}$} & Coliformes Fecais & $<500 \mathrm{NPM} / 100 \mathrm{~mL}$ \\
\hline & & & Oxigênio Dissolvido & $>2,0 \mathrm{mg} / \mathrm{L}$ \\
\hline
\end{tabular}

\section{SISTEMA DE TRATAMENTO DE ÁGUAS CINZAS}

A Estação de Tratamento de Águas Cinzas ETAC, ilustrada pelo esquema da Figura 01, recebe inicialmente o efluente em um tanque de sedimentação, dimensionado conforme NBR 13969 (1997). Posteriormente, devido ao próprio fluxo de descargas, o efluente é conduzido para um filtro composto por uma camada de $60 \mathrm{~cm}$ de brita no1 e outra de $60 \mathrm{~cm}$ areia média peneirada com taxa de filtração de $2,28 \mathrm{~m}^{3} / \mathrm{m}^{2}$. dia, o que caracteriza o filtro como lento. Ao passar pelo filtro, o efluente tratado é conduzido para um reservatório com capacidade de $600 \mathrm{~L}$, suficiente para suprir a demanda de água para a irrigação da área verde da residência.

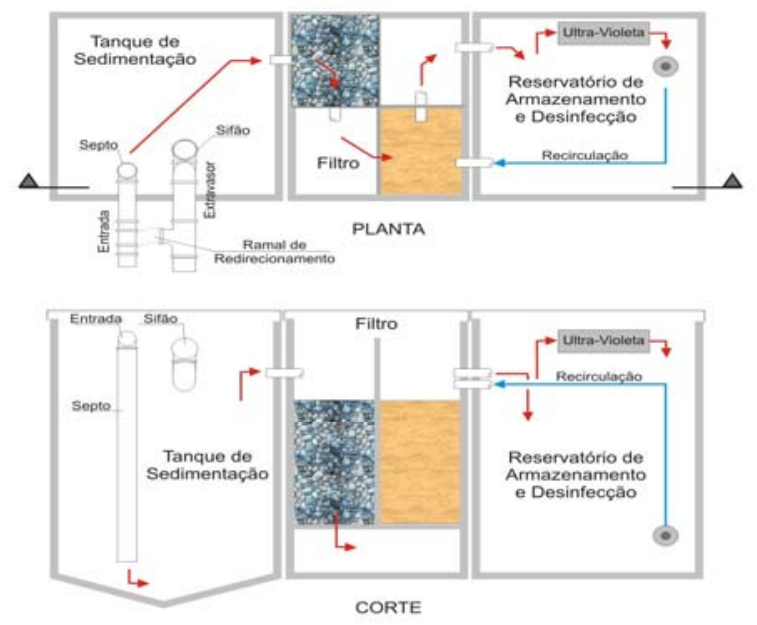

Figura 01: Detalhe esquemático do sistema de tratamento de águas cinza (ETAC).
Fonte: REIS et al., (2009).
Neste reservatório, foram instalados um sistema de desinfecção por UV e uma bomba que promove o retorno do efluente para o sistema de filtração, programada para funcionar 8 horas diárias em intervalos igualmente espaçados de 30 minutos. A Figura 02 ilustra as células do sistema de tratamento, com tanque de sedimentação, filtro e reservatório.

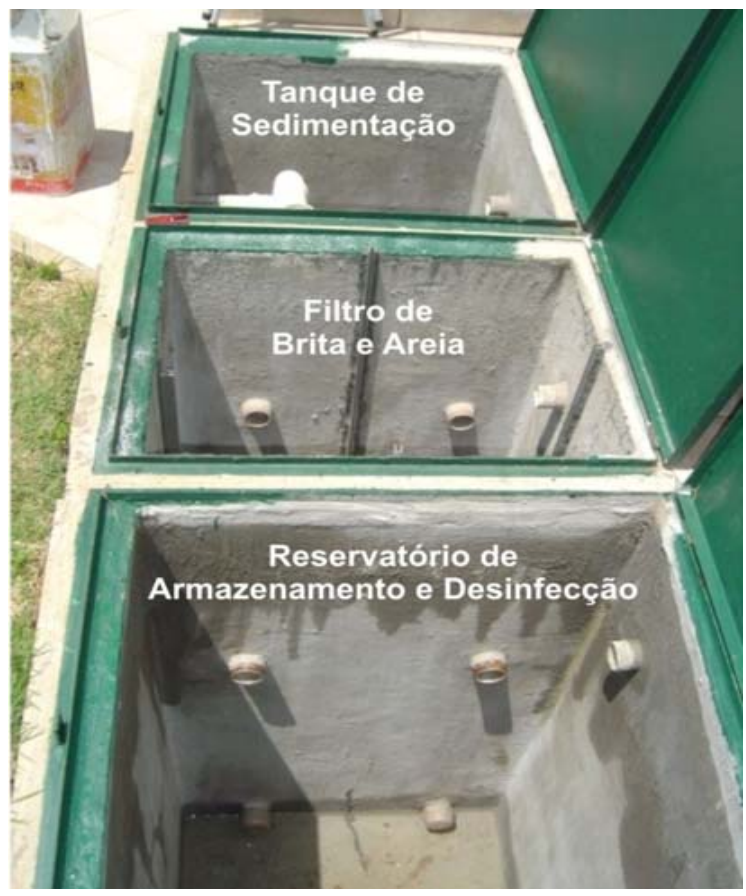

Figura 02: Células do sistema de tratamento. Fonte: REIS et al., (2009). 
O volume de efluente de esgoto secundário gerado pela residência habitada por duas pessoas foi monitorado por duas semanas, onde foram medidas descargas diárias na faixa entre $74,15 \mathrm{~L}$ e $382,8 \mathrm{~L}$, sendo a média diária igual a 170,24L. O efluente chega ao tanque de sedimentação por meio de um septo afogado, que favorece a sedimentação de materiais sólidos. Quando um volume maior chegava ao sistema de tratamento, com ele operando em sua capacidade máxima, o excedente é conduzido por meio de um extravasor para a rede pública de esgoto. Neste extravasor, foi instalado um sifão com intuído de impedir o retorno de odores e insetos para dentro do sistema. Caso o sistema precise ser desligado, foi previsto um ramal de redirecionamento do efluente secundário que permite interromper a entrada de esgoto no sistema de tratamento conduzindo-o diretamente para a rede primária.

\subsection{Tubulações Independentes e Ramal de Redirecionamento}

O esgoto proveniente de chuveiros, máquina de lavar roupa, lavatórios e tanques são coletados por tubulações independentes (Figura 03), e em caso da interrupção de funcionamento do sistema, existe um dispositivo acoplado a uma curva de $90^{\circ}$ na tubulação de captação, a qual desvia o curso da água cinza, encaminhando esta à rede pública de coleta de esgoto. O processo de desativação do sistema com remoção das luvas e a conexão da curva de redirecionamento são feitos manualmente, utilizando-se conexões com junta elástica (Figuras 04 e 05).

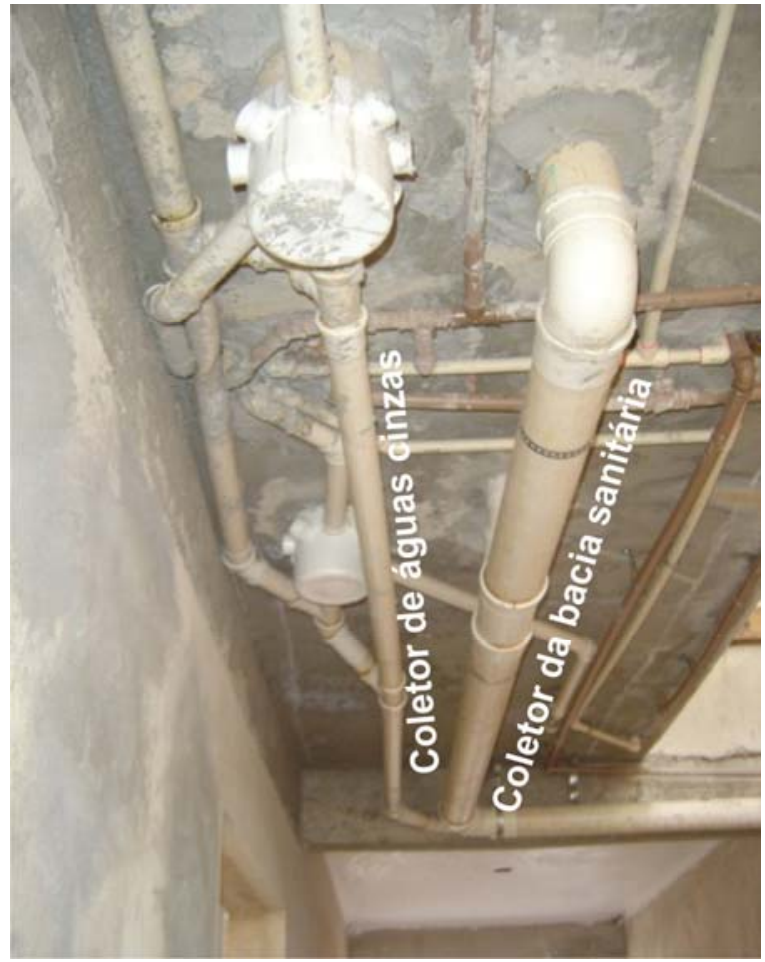

Figura 03: coletores independentes para água cinza e negra. Fonte: REIS et al., (2009).

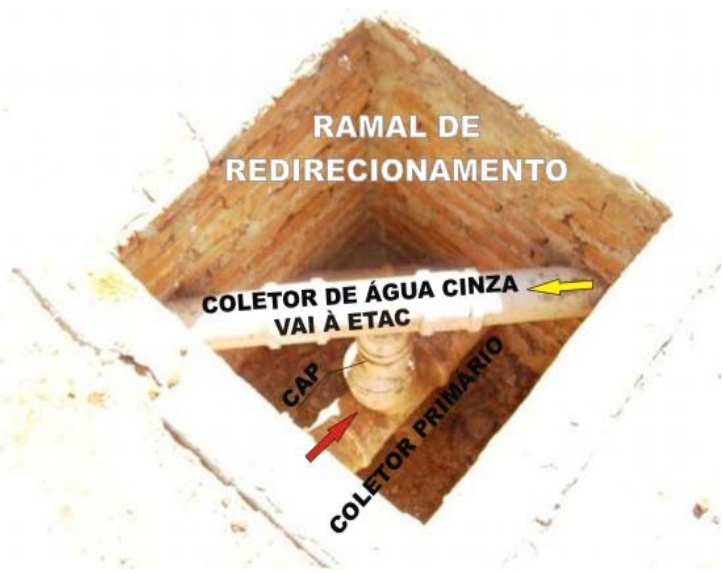

Figura 04: Ramal de redirecionamento conectado ao sistema de tratamento de águas cinza - ETAC.

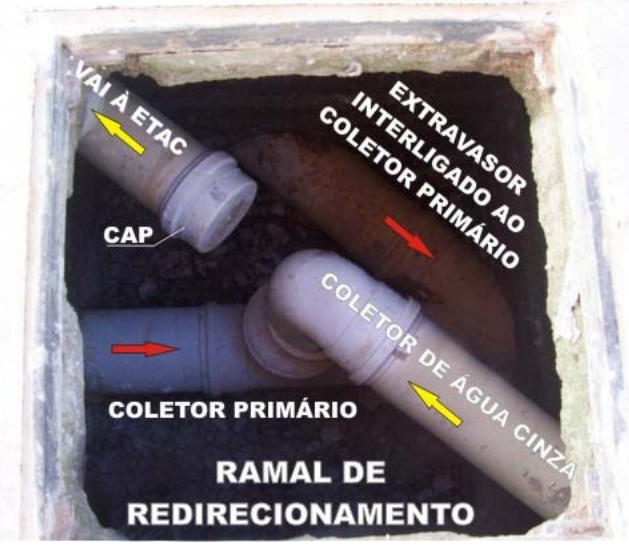

Figura 05: Ramal de redirecionamento desviando esgoto para a rede primária esgoto e coletor público.

\subsection{Célula 1: Tanque de Sedimentação}

A sedimentação consiste em movimentos descendentes das partículas suspensas em meio líquido de menor massa específica, as quais terão seu movimento acelerado pela lei da gravidade até que estas se igualem à força de deformação do líquido, juntamente ao empuxo, quando sua velocidade será constante.

No caso específico do sistema em estudo, a sedimentação age separando as partículas sólidas com maior peso específico do que o da água cinza, antes que a água atinja a próxima no seu tratamento, ou seja, o filtro.

O tanque de sedimentação estudado recebe as águas cinza (chuveiros, lavatórios, tanque, banheiros e área de serviço), possui as dimensões de $80 \mathrm{~cm}$ de lado e $85 \mathrm{~cm}$ de profundidade, tem capacidade de armazenar 544L. A descarga de águas cinza no tanque de sedimentação ocorre por uma tubulação de $75 \mathrm{~mm}$ de diâmetro, onde foi instalado o septo afogado (Figura 06). Como extravasor, foi instalada uma tubulação de $100 \mathrm{~mm}$ de diâmetro, formando um sifão, para evitar o retorno de odores e entrada de insetos, e um vertedor tipo tulipa (Figuras 06 e 07). 
Ainda no tanque de sedimentação, foi instalada uma ventilação com $50 \mathrm{~mm}$ de diâmetro, com o objetivo de evitar o acúmulo de gases do esgoto público à residência (Figura 07).

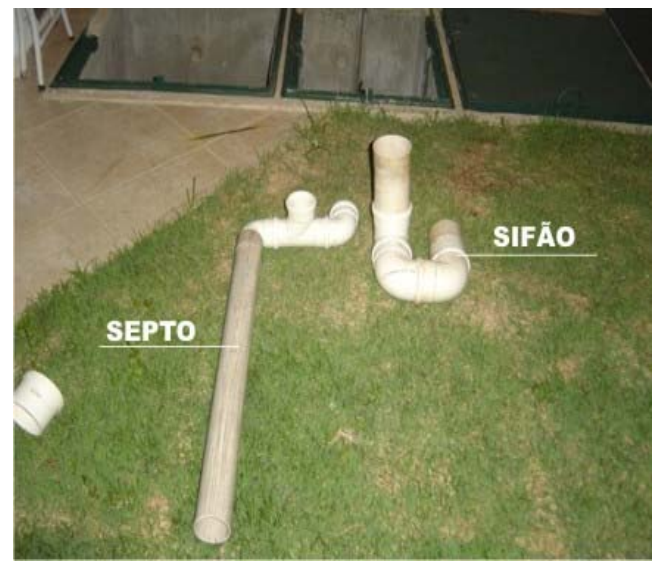

Figura 06: Septo afogado e extravasor com sifão.

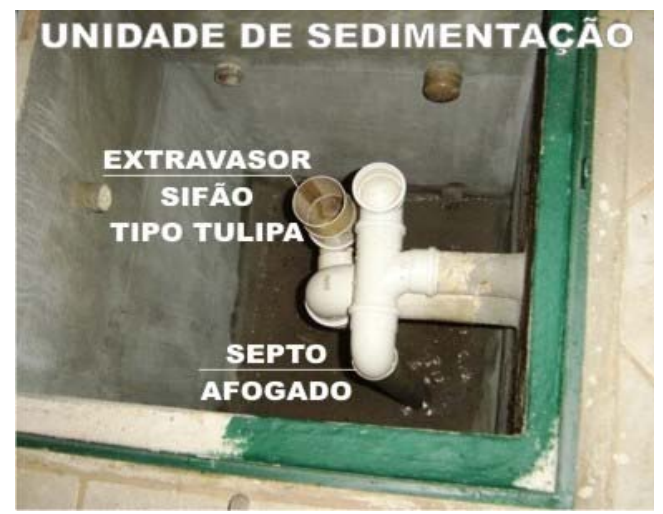

Figura 07: Sistema de sifão do extravasor e septo instalado.

A tubulação de $75 \mathrm{~mm}$ de diâmetro foi acoplada a um septo afogado, onde a descarga de água se dá pelo fundo, promovendo assim o processo de sedimentação

A limpeza deste sistema será manual, após o esvaziamento do tanque por meio do bombeamento da água cinza, a qual será conduzida para a rede pública de esgoto utilizando o extravasor.

\subsection{Célula 2: Filtro}

A filtração estudada neste experimento foi caracterizada como lenta e de fluxo descendente pelo filtro. As dimensões deste filtro compartimentado são $80 \mathrm{~cm}$ de comprimento, $60 \mathrm{~cm}$ de largura e $85 \mathrm{~cm}$ de profundidade, com capacidade de armazenar $408 \mathrm{~L}$. 0 filtro possui também oito conexões de $60 \mathrm{~mm}$, sendo quatro para sua ligação com o tanque de sedimentação, e quatro para o reservatório de armazenamento e desinfecção. Assim como as demais unidades, o filtro também possui uma tubulação que promove sua ventilação.

A montagem do filtro necessitou de fundos falsos, com a finalidade de evitar que partículas ou material do filtro não passassem para o reservatório ou para o tanque de sedimentação, por meio dos tubos de comunicação (Figuras 08 e 09). Tais fundos falsos são feitos de alumínio, espaçados a uma altura de $20 \mathrm{~cm}$ do fundo. O filtro foi repartido em quatro câmaras iguais, utilizando-se material plástico em trilhos de alumínio situados nas paredes, fundo e centro do reservatório.

Para impedir a água de passar entre a junção do trilho e a parede, colocou-se adesivo epóxi, aderindo o material à parede; entre o trilho e o material plástico, utilizou-se cola silicone, evitando situação semelhante.

Os locais de saída de água dos filtros demandaram cortes retangulares na parte inferior da chapa de plástico, abaixo do fundo falso, assegurando que a água passasse totalmente pelo filtro de brita. $\mathrm{Na}$ entrada da segunda câmara do filtro foi feito um corte retangular na parte superior deste, afim de que a água entrasse na parte superior do filtro de areia.

\subsection{Meios filtrantes}

O sistema filtrante é composto por brita numa câmara e areia na outra, sendo que nas câmaras foram colocadas mantas de poliéster no fundo e parede, formando uma espécie de "saco", evitando que os materiais filtrantes saiam do lugar planejado.

O filtro, mostrado pela Figura 10 possui a composição de areia média e brita $\mathrm{n}$ 으, depositados em suas câmaras por gravidade, a uma altura inferior à $50 \mathrm{~cm}$, de forma a promover uma baixa compactação dos grãos. A camada de brita e areia tem altura de $60 \mathrm{~cm}$.

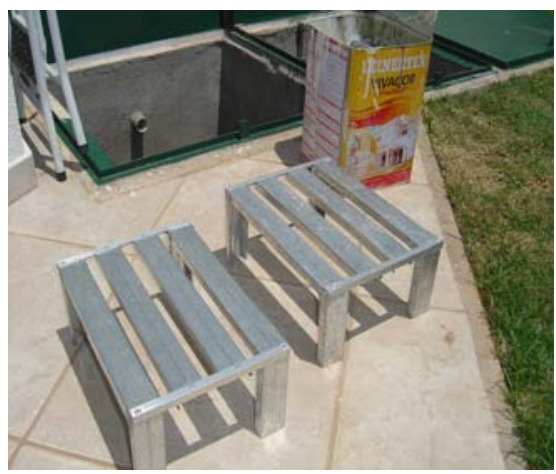

Figura 08: Fundo falso de alumínio

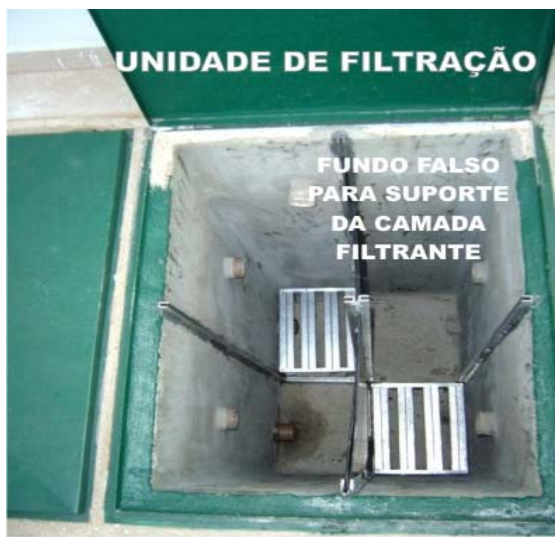

Figura 09: Fundo falso e divisórias de compartimentação dos filtros 


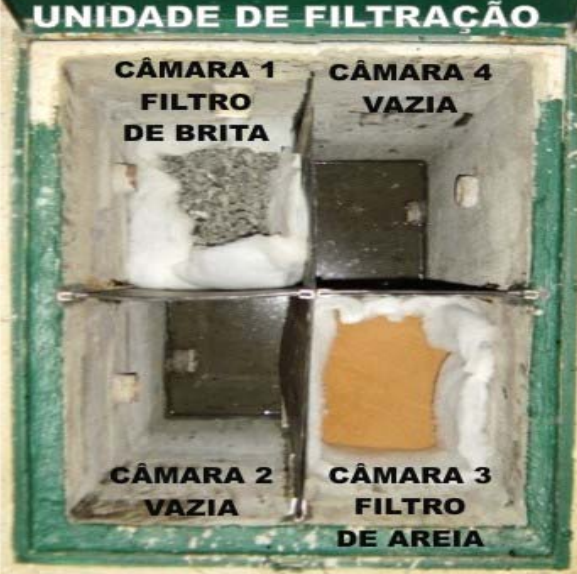

Figura 10: Filtro com materiais filtrantes envoltos pela manta de pena de poliéster.

\subsubsection{Brita}

A brita utilizada possui diâmetro máximo de $19 \mathrm{~mm}$ e mínimo de 9,5mm, depositada, posteriormente, filtro em uma câmara de seção transversal de $39 \mathrm{~cm}$ de comprimento, $30 \mathrm{~cm}$ de largura, $60 \mathrm{~cm}$ de profundidade, ocupando o volume de 70,2L.

O material utilizado para a composição desta camada filtrante foi submetido a ensaios granulométricos, gerando seu peso específico $\left(\nu_{\mathrm{b}}\right)$, índice de vazios $(e)$, peso da brita $\left(P_{b}\right.$, relação entre peso do recipiente vazio e com brita), peso da água $\left(P_{w}\right.$ $\left.=1 \mathrm{~g} / \mathrm{cm}^{3}\right)$, volume da brita $\left(V_{b}\right.$, relação entre $V_{r}$ e $\left.P_{w}\right)$, volume de vazios $\left(V_{v}\right)$, volume total $\left(V_{t}\right)$, volume do recipiente vazio $\left(V_{r}\right)$, conforme os valores a seguir:

- $\gamma_{\mathrm{b}}=2,50 \mathrm{~g} / \mathrm{cm}^{3}$;

- $\mathrm{e}=0,65$;

- $P_{b}=106,36 \mathrm{Kg}$ (no filtro)

- $\mathrm{V}_{\mathrm{b}}=42.545 \mathrm{~cm}^{3}$ (no filtro);

- $\mathrm{V}_{\mathrm{v}}=27.655 \mathrm{~cm}^{3}$ (no filtro);

- $\mathrm{V}_{\mathrm{t}}=70.200 \mathrm{~cm}^{3}$ (no filtro);

Ressalta-se que a brita possui a função de formar uma colônia de bactérias para degradação da matéria orgânica presente na água, devido ao seu alto índice de vazios (e), o que também permitiu altas taxas de permeabilidade e infiltração.

\subsubsection{Areia}

A areia foi depositada em uma câmara com dimensões iguais à da camada com brita, $30 \times 39 \times 60 \mathrm{~cm}$, cujo volume equivale a 70,2L. Tal camada filtrante foi envolta por manta de pena de poliéster, impedindo a passagem deste ao fundo da célula e para as demais unidades do sistema. A altura da areia depositada na câmara foi menor do que $50 \mathrm{~cm}$, gerando uma energia de compactação devido à ação do peso pela gravidade insignificante, produzindo uma areia fofa.

A vazão média de água foi 170,24L por dia, gerando uma taxa de filtração, em laboratório, de 2,28 $\mathrm{m}^{3} / \mathrm{m}^{2}$. dia; porém, considerou-se para a filtração menor do que $200 \mathrm{~m}^{3} / \mathrm{m}^{2}$. dia. Através da relação abaixo, utilizando a área da câmara com areia, e a vazão obtida $\left(0,17024 \mathrm{~m}^{3}\right)$, obteve-se a taxa de filtração (y) de valor igual a $1,45 \mathrm{~m}^{3} / \mathrm{m}^{2}$. dia.

$$
\begin{gathered}
0,17024 \mathrm{~m}^{3} \leftrightarrow 0,117 \mathrm{~m}^{2}(30 \mathrm{~cm} \times 39 \mathrm{~cm}) \\
y \leftrightarrow 1 \mathrm{~m}^{2} \\
y=1,4545 \mathrm{~m}^{3} / \mathrm{m}^{2} . \text { Dia }
\end{gathered}
$$

Di Bernardo (1993) recomenda, entre outros:

- Espessura da camada entre 0,6-0,8m;

- Coeficiente de desuniformidade $\leq 1,6$;

- Tamanho dos grãos entre 0,42-1,41mm;

- Tamanho efetivo entre 0,45-0,55mm.

Os ensaios realizados em laboratório da Escola de Engenharia Civil (EEC) da Universidade Federal de Goiás (UFG), com peneirador mecânico e manualmente (Figuras 11 e 12), caracterizaram a densidade real dos grãos (peso específico da areia), granulometria por peneiramento (diâmetro dos grãos e classificação), permeabilidade (taxa de infiltração do solo) e moldagem de corpo.

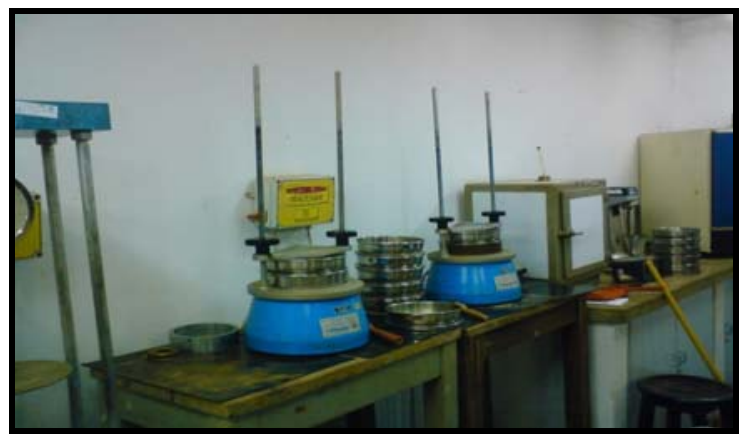

Figura 11: Peneiramento mecânico da areia média.

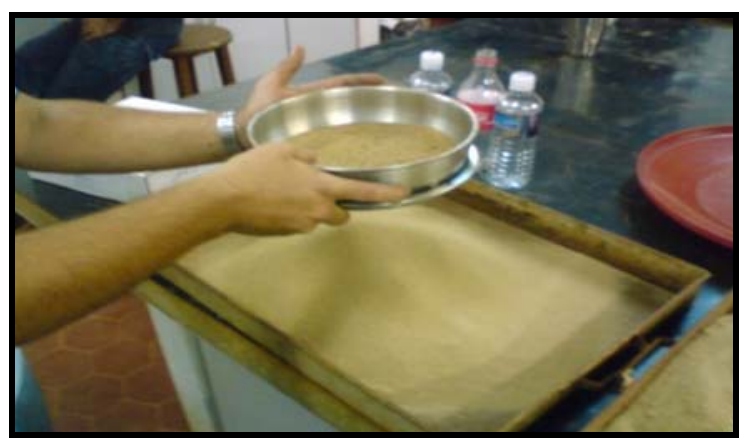

Figura 12: Peneiramento manual da areia para a unidade de filtração.

Os resultados obtidos foram divididos conforme os ensaios de peneiramento, densidade real dos grãos e ensaio de permeabilidade à carga constante.

No ensaio de peneiramento, os seguintes parâmetros foram estudados, segundo Soares et al. (2006):

- Diâmetro efetivo (D10) é o ponto característico da curva granulométrica para medir a finura do solo, que corresponde ao ponto de $10 \%$, tal que $10 \%$ das partículas do solo possuem diâmetro inferior a ele. 
- Coeficiente de não uniformidade (CNU) dimensionado conforme a Equação 2, qualifica a distribuição do tamanho das partículas do solo; valores próximos de um indicam curva granulométrica quase vertical, com os diâmetros variando em um intervalo pequeno, enquanto que, para valores maiores a curva granulométrica irá se abatendo e aumentando o intervalo de variação dos diâmetros. Da mesma foram que foi definido D10, define-se D30 e D60.

$$
C N U=\frac{D 60}{D 10} \quad \text { Equação (2) }
$$

- Coeficiente de curvatura (CC) dimensionado conforme a Equação 3, é a medida da forma e da simetria da curva granulométrica e é igual a:

$$
C C=\frac{(D 30)}{D 10 \cdot D 60}
$$

Equação (3)

Para um solo bem graduado, o valor do coeficiente de curvatura, deverá estar entre 1 e 3. Portanto, a distribuição do tamanho de partículas é proporcional, de forma que os espaços deixados pelas partículas maiores sejam ocupados pelas menores. Para solos granulares há maior interesse no conhecimento do tamanho das partículas, visto que, algumas de suas propriedades estão relacionadas com os mesmos, o que não ocorre com os solos finos.

No ensaio de peneiramento realizado, $36 \%$ do solo passaram na peneira 60 (D60) e $18 \%$ na 10 (D10), o valor de CNU foi igual a 2, e o de CC igual a 1,09.

A densidade real dos grãos consiste na razão entre o peso especifico real dos grãos ( $\gamma s$ ) e o peso específico da água a $4^{\circ} \mathrm{C}$. Este foi realizado com auxílio do picnômetro (balão volumétrico). Portanto, a densidade real obtida $\left(\nu_{\mathrm{a}}\right)$ foi de $2,633 \mathrm{~g} / \mathrm{cm}^{3}$;

No ensaio de permeabilidade à carga constante a amostra é submetida a uma carga hidráulica constante durante o ensaio (permeâmetro de nível constante). O coeficiente de permeabilidade é determinado pela quantidade de água que percola a amostra para um dado intervalo de tempo. A quantidade de água é medida por uma proveta graduada, determinando-se a vazão (Q).

O solo deveria estar compactado a $70 \%$, como preconiza a NBR 13292, ABNT (1995), porém, no ensaio tentando ilustrar a realidade, foi depositada a amostra de areia no cilindro de teste, como foi no filtro, e obteve-se um grau de compactação de $37,90 \%$.

\subsection{Reservatório}

A função desta unidade é armazenar a água cinza filtrada antes do seu destino final, utilizado neste caso para irrigação de jardins, com capacidade e dimensões iguais ao tanque de sedimentação. Este é composto de quatro tubos de $60 \mathrm{~mm}$, que podem permitir a entrada pelo fundo do ou por cima da unidade de filtração, e a uma tubulação de $50 \mathrm{~mm}$ (ventilação). Neste foram instalados dois timers, duas bombas, um aerador e o aparelho de desinfecção por ultravioleta (Figura 13).

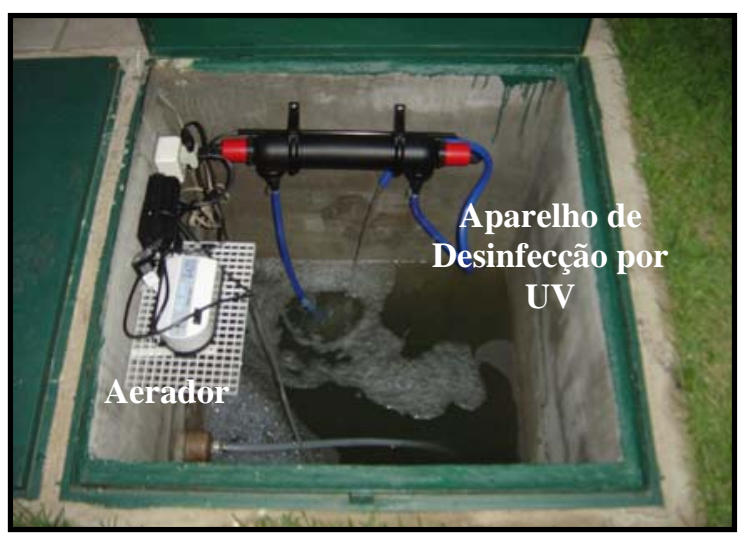

Figura 13: Reservatório com equipamentos instalados.

Um timer ativa a bomba para a recirculação, funcionando por oito horas, e o outro na desinfecção das águas cinza, agindo por dez horas, e ambos são programados pelo usuário do sistema. A bomba de recirculação possui vazão máxima de $2.000 \mathrm{~L} / \mathrm{h}$, mas como a capacidade de filtração é baixa, esta foi programada para funcionar oito horas por dia, em oito intervalos uniformemente espaçados durante o dia, evitando o retorno da água para o tanque de sedimentação e consecutivo extravasamento.

A bomba que serve para a passagem da água pelo aparelho de desinfecção por ultravioleta possui uma vazão máxima de 600L/h, e também é ligada ao timer, com funcionamento de $10 \mathrm{~h}$ diariamente (dois intervalos de cinco horas). Há também no reservatório um aerador, com vazão de ar de 4L/min., que funciona dez horas por dia, em dois intervalos de cinco horas.

\subsection{Desinfecção por ultravioleta}

Di Bernardo (1993) caracteriza a desinfecção por raios ultravioleta conforme sua fonte: natural (sol) e não natural (lâmpadas incandescentes). No sistema em estudo, utilizou-se uma unidade de filtro de UV para a eliminação de microrganismos patogênicos, o qual emprega uma lâmpada incandescente (vapor de mercúrio), com $15 \mathrm{~W}$ de potência, e envolvida com uma luva de quartzo que tem a finalidade de preservar a lâmpada e esta opera em sua intensidade máxima.

O sistema consiste em uma bomba, com vazão regular de 300 a $600 \mathrm{~L} / \mathrm{h}$, a qual injeta água já filtrada no aparelho de desinfecção UV, para sua desinfecção que possui saída de água em outra extremidade. Conforme a lâmpada UV emite raios na água contaminada, estes são absorvidos pelos ácidos nucléicos e proteínas, causando alterações bioquímicas ou quebra de moléculas, gerando sua morte. 
A manutenção periódica é necessária para a eficácia do equipamento, consistindo na lavagem do tubo de quartzo, o qual, devido à presença da água contaminada, cria crostas de biofilme que impedem a propagação dos raios UV na água. Para uma melhor avaliação da periodicidade de manutenção, sugere-se monitorar, também, ensaios bacteriológicos, os quais confirmam o devido funcionamento da lâmpada, a qual deve emitir raios com comprimento de onda adequados à desinfecção da água.

\section{RESULTADOS E DISCUSSÃO}

Por meio das análises das amostras retiradas do sistema de reúso, realizadas no primeiro mês, nos dias 13/10, 03/11 e 17/11, obteve-se o gráfico da Figura 14, o qual ilustra a evolução da melhora da qualidade da água após passar pelo sistema de tratamento, caracterizada pela maturação dos filtros. A Figura 15 ilustra a amostra retirada juntamente com a terceira coleta, e permite uma avaliação visual do aspecto da água tratada, evidenciando uma melhora de qualidade desta.

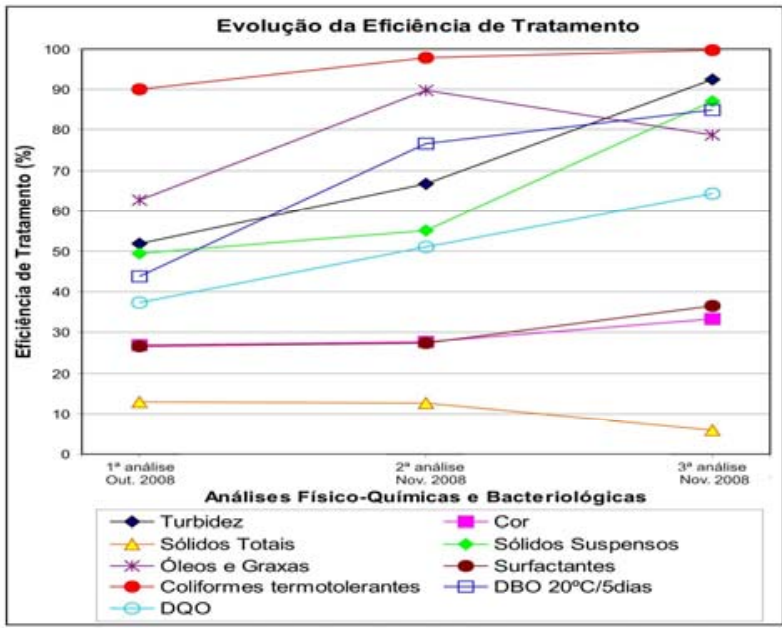

Figura 14: Evolução da eficiência do sistema de tratamento durante o período de maturação dos filtros.

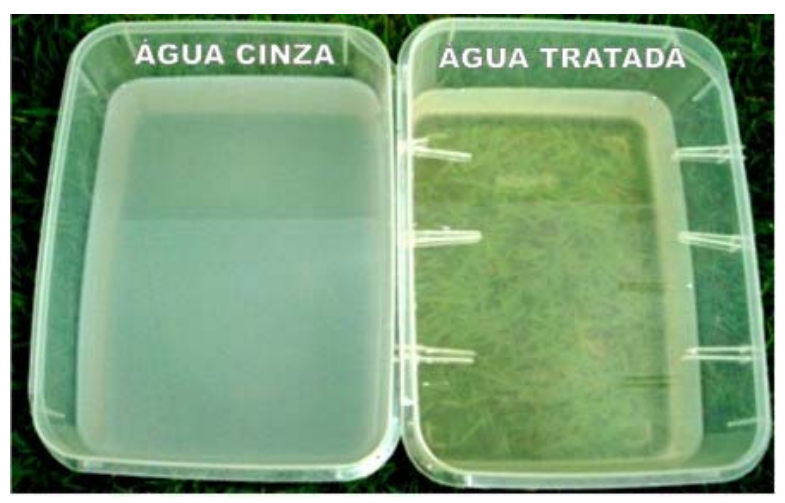

Figura 15: Comparação entre água antes e após tratamento.

O gráfico da Figura 16 ilustra a eficiência média de tratamento do sistema, durante o período de estudo, que foi interrompido no 5ㅇ mês, devido ao rompimento da câmara de brita na unidade de filtração.

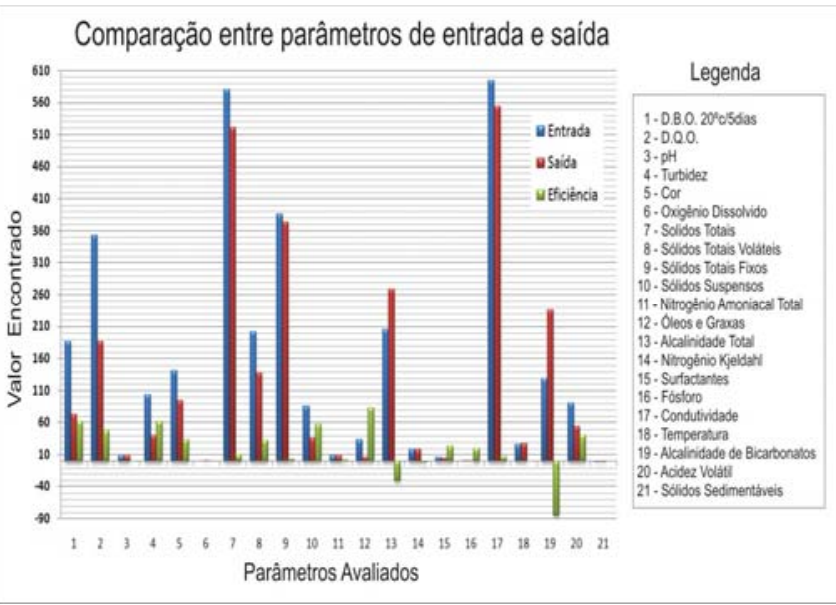

Figura 16: Eficiência obtida por meio da comparação entre os parâmetros de qualidade da água entrada e saída do sistema de tratamento.

Os valores máximos, mínimos e médios de qualidade da água obtidos nos dias 13/10/08, 03/11/08, 17/11/08, 08/12/08, 22/12/08, 08/01/09, 20/01/09 e 09/02/09, na entrada do sistema, antes do tratamento e após este constam no Quadro 05 a seguir. Ressalta-se que os dados avaliados no dia 25/05/09, quando houve o rompimento do filtro, foram desprezados, pois não representam a real eficiência do sistema de tratamento da unidade estudada.

Quanto à vazão de suprimento de água de reúso, calcularam-se seus valores obtidos do monitoramento das vazões, considerando os dias em que as medições foram realizadas conforme a semana, com o sistema em funcionamento, foram gerados os seguintes valores:

- Vazão média diária monitorada na 1ạ semana (08/10/08-14/10/08): 130,65L/dia

- Vazão média diária monitorada na 2a semana (15/10/08-19/10/08): 220,87L/dia

- Vazão média diária monitorada na 3ạ semana (23/10/08-26/10/08): 159,22L/dia

- Média das vazões diárias obtidas: $\sum\langle 130,65+220,87+159,22\rangle \div 3=170,24 \mathrm{~L} / \mathrm{dia}$

Ressalta-se que o valor médio das vazões, de 170,24 L/dia, quando utilizado em um mês (30 dias), resultaria numa economia de reúso de água de 5.107,2L por mês.

Os cálculos de volume do sistema de reúso de águas cinza da edificação unifamiliar, e seus valores para o reúso na irrigação foram:

- Supondo a utilização de 170,24 L/dia x 30 dias (mês), totaliza-se $5.107,2 \mathrm{~L} /$ mês, ou $5,1 \mathrm{~m}^{3} /$ mês de água de reúso;

- A utilização desta água em floreira, especificamente, numa área de $7,55 \mathrm{~cm} \times 0,60 \mathrm{~cm}$, ou seja, $4,5 \mathrm{~m}^{2}$; 
utilizando a vazão de 170,24 L/dia dividida pela área de $4,5 \mathrm{~m}^{2}$, disponibilizaria $37,83 \mathrm{~L} / \mathrm{m}^{2}$;

- As áreas da floreira, verde e gramada, em conjunto, têm $42 \mathrm{~m}^{2}$, e geraria um consumo de $170,24 \div$ $42 \mathrm{~m}^{2}$, equivalente a $4,053 \mathrm{~L} / \mathrm{m}^{2}$;

- A economia de água do sistema, de $5,1 \mathrm{~m}^{3}$, teria um custo de $5,1 \mathrm{~m}^{3} \times \mathrm{R} \$ 1,88 /$ mês (referente ao tratamento de água), totalizando $\mathrm{R} \$$ 9, 588; acrescentando-se 5,1 $\mathrm{m}^{3} \times \mathrm{R} \$ 1,13 /$ mês (referente ao tratamento de esgoto) obtêm-se o valor de $\mathrm{R} \$$, 424, e totalizaria $R \$ 15,35 /$ mês de economia.

O custo operacional, destacando-se o consumo de energia, gerou os seguintes valores calculados pela relação:

- Potência x no de horas utilizadas por dia x nํ de dias por mês de uso $\div 1.000$;

- Bomba de recirculação: $(45 \mathrm{~W} \times 8 \mathrm{~h} \times 30) \div 1.000=$ 10,8 kWh/mês;

- Filtro UV: $(15 \mathrm{~W} \times 10 \mathrm{~h} \times 30) \div 1.000=$ 4,5 kWh/mês;

- Bomba de filtro UV: $(13 \mathrm{~W} \times 10 \mathrm{~h} \times 30) \div 1.000=$ 3,9 kWh/mês;
- Aerador de 4 L/min: $(6 \mathrm{~W} \times 10 \mathrm{~h} \times 30) \div 1.000=1,8$ kWh/mês;

- Total: 21,0 kWh/mês;

- Custo do kWh - R\$ 0, $450720 \times 21,0 \mathrm{kWh} / \mathrm{mês}=\mathrm{R} \$$ 9, 465/mês

Os custos de implantação do sistema foram:

- Estrutura (reservatórios, impermeabilização, tampas metálicas e mão-de-obra): R\$ 1.400,00.

- Equipamentos:

- Bomba de recirculação sub., 45 W: $\mathrm{R} \$ 150,00$

- Bomba de recirculação do filtro UV, 13W: $R \$ 65,00$

- Filtro UV, 15W: $\mathrm{R} \$ 400,00$

- Mangueira com micro furos + aerador: $\mathrm{R} \$ 30,00+$ $\mathrm{R} \$ 55,00$

- $\quad$ Alumínio + placas + manta de poliéster: $\mathrm{R} \$ 80,00+$ $R \$ 54,00+R \$ 30,00$

- Silicone (4 tubos): $\mathrm{R} \$ 60,00$

- Total: $\mathrm{R} \$ 2.324,00$

Subtraindo-se a economia no reúso de água ( $R \$$ $15,351)$ do consumo de energia elétrica ( $R \$ 9,465)$, obteve-se uma economia total de $\mathrm{R} \$ 5,886$ por mês, desconsiderando-se o custo das análises de qualidade

Quadro 05: Média dos valores de parâmetros de qualidade de água na entrada e saída do sistema de tratamento de águas cinza.

\begin{tabular}{|c|c|c|c|c|c|c|}
\hline & \multicolumn{6}{|c|}{ Monitoramento entre $13 / 10 / 2008$ e 09/02/2009 } \\
\hline & $\begin{array}{c}\text { Valor } \\
\text { máximo } \\
\text { (Entrada) }\end{array}$ & $\begin{array}{c}\text { Valor } \\
\text { mínimo } \\
\text { (Saída) }\end{array}$ & Entrada & Saída & Eficiência & Unidade \\
\hline D.B.0. 20C/5dias & 300 & 25 & 186,6 & 72,6 & 61,09 & $\mathrm{mg} / \mathrm{L} . \mathrm{O}_{2}$ \\
\hline D.Q.O. & 480,6 & 115,3 & 352,7 & 186,8 & 47,04 & $\mathrm{mg} / \mathrm{L} . \mathrm{O}_{2}$ \\
\hline pH & - & - & 8,0 & 8,0 & & \\
\hline Turbidez & 168 & 7 & 103,1 & 39,9 & 61,32 & UNT \\
\hline Cor & 245 & 53 & 141,1 & 94,4 & 33,10 & $\mathrm{Pt} / \mathrm{L}$ \\
\hline Oxigênio Dissolvido & 0 & 4,9 & 0,0 & 0,8 & --- & $\mathrm{mg} / \mathrm{L} \mathrm{O}_{2}$ \\
\hline Solidos Totais & 655 & 467 & 580,0 & 520,9 & 10,19 & $\mathrm{mg} / \mathrm{L}$ \\
\hline Sólidos Totais Voláteis & 210 & 77 & 201,7 & 137,0 & 32,07 & $\mathrm{mg} / \mathrm{L}$ \\
\hline Sólidos Totais Fixos & 413 & 292 & 385,3 & 373,7 & 3,03 & $\mathrm{mg} / \mathrm{L}$ \\
\hline Sólidos Suspensos & 148 & 17 & 85,8 & 36,4 & 57,58 & $\mathrm{mg} / \mathrm{L}$ \\
\hline $\begin{array}{l}\text { Nitrogênio Amoniacal } \\
\text { Total }\end{array}$ & 15,7 & 2,52 & 8,9 & 8,6 & 2,40 & $\mathrm{mg} / \mathrm{L} \mathrm{N}$ \\
\hline Óleos e Graxas & 68,8 & 2 & 33,6 & 5,6 & 83,25 & $\mathrm{mg} / \mathrm{L}$ \\
\hline Alcalinidade Total & 250 & 180 & 205,7 & 268,6 & $-30,56$ & $\begin{array}{l}\mathrm{mg} / \mathrm{L} \\
\mathrm{CaCO}_{3} \\
\end{array}$ \\
\hline Nitrogênio Kjeldahl & 17,3 & 6,72 & 18,2 & 18,6 & $-2,36$ & $\mathrm{mg} / \mathrm{L}$ \\
\hline Surfactantes & 16,2 & 0,73 & 5,7 & 4,3 & 23,92 & $\mathrm{mg} / \mathrm{L} \mathrm{LAS}$ \\
\hline Fósforo & 2,02 & 0,01 & 1,3 & 1,1 & 19,13 & $\mathrm{mg} / \mathrm{L} \mathrm{P}$ \\
\hline Condutividade & 594 & 554 & 594,0 & 554,0 & 6,73 & $\mu \mathrm{S} / \mathrm{cm}$ \\
\hline Temperatura & 27,6 & 25,7 & 26,5 & 26,9 & --- & $\stackrel{\circ}{\mathrm{C}}$ \\
\hline $\begin{array}{l}\text { Alcalinidade de } \\
\text { Bicarbonatos }\end{array}$ & 146,8 & 166 & 127,8 & 235,8 & $-84,53$ & $\begin{array}{l}\mathrm{mg} / \mathrm{L} \\
\mathrm{CaCO}_{3}\end{array}$ \\
\hline Acidez Volátil & 108 & 24 & 90,2 & 54,2 & 39,89 & $\begin{array}{l}\mathrm{mg} / \mathrm{L} \\
\mathrm{CaCO}_{3} \\
\end{array}$ \\
\hline Solidos Sedimentáveis & 0,1 & 0,1 & 0,1 & 0,1 & 0,00 & $\mathrm{~mL} / \mathrm{L} / \mathrm{h}$ \\
\hline $\begin{array}{l}\text { Coliformes } \\
\text { Termotolerantes }\end{array}$ & $3,05 E+06$ & $1,80+\mathrm{E} 03$ & $9,56 \mathrm{E}+05$ & $1,05 E+05$ & 88,97 & $\begin{array}{l}\text { N.M.P. } \\
\text { 100mL }\end{array}$ \\
\hline
\end{tabular}


de água realizadas, que tem um valor de $\mathrm{R} \$ 178,00$ por análise, ou o custo das análises básicas de cor, turbidez, $\mathrm{pH}$ e coliformes termotolerantes, as quais totalizariam em $\mathrm{R} \$ 45,00$, aproximadamente.

A avaliação de "payback" do sistema de tratamento de águas cinza, do ponto de vista econômico, desconsiderando os custos em análises de água, através da Equação 4 abaixo, resultou nos seguintes valores:

$$
\mathrm{AF}=\mathrm{B} /(1+\mathrm{r})^{\mathrm{t}} \quad \text { Equação (4) }
$$

Onde:

$A F=$ fluxo de benefício atualizado

$B=$ fluxo de benefício

$\mathrm{B}=\mathrm{C} 1$ (valor antes da conta intervenção) - C2(valor esperado após intervenção)

$r=$ taxa de desconto (+/- $10 \%$ ao ano)

$\mathrm{t}=$ período de análise

Utilizando os dados de economia de água obtidos, onde a economia de água por mês foi de R\$ 15,351 , e consumo de energia foi de $R \$ 9,465$, o valor de $B$ seria a diferença entre os dois valores, ou seja, $R \$$ 5 , 886. Para as simulações de $0 \%$ aa e $10 \%$ aa de taxa de desconto, as Equações 5 e 6 obtiveram os seguintes valores, respectivamente:

$$
\begin{array}{ll}
A F=(5,886 \times 12) /(1+0,00)^{1 \text { ano }} & \text { Equação (5) } \\
A F=R \$ 70,63(r=0 \%) & \\
A F=(5,886 \times 12) /(1+0,10)^{1 \text { ano }} & \text { Equação (6) } \\
A F=R \$ 64,21(r=10 \%) &
\end{array}
$$

Avaliando as simulações feitas para $r=0 \%$ aa e $10 \%$ aa, obtiveram-se tempos de 34 e 38 anos, respectivamente, o que demonstra, em ambos os casos, um longo tempo para a obtenção de um possível "payback" (retorno), do ponto de vista econômico, na utilização do sistema de reúso de águas cinza estudado.

\section{CONCLUSÃO}

O sistema de reúso de águas cinza estudado demonstrou uma eficiência de tratamento considerável, em se tratando de um sistema anaeróbio, a exceção do sistema de desinfecção UV, devido á formação de uma camada de biofilme sobre a luva de quartzo, a qual envolveu a lâmpada; recomenda-se, portanto, utilizar o sistema UV onde a lâmpada não fique submersa ao líquido. O material divisor do sistema de filtração também apresentou resistência inadequada, sendo necessário substituí-lo por material mais rígido após cinco meses de funcionamento do filtro.

O desempenho do sistema de tratamento foi adequado aos valores de eficiência de um sistema anaeróbico, porém, a maioria dos parâmetros de qualidade da água de reúso foi insatisfatória aos critérios sugeridos por FIESP (2005) e US EPA (2004). Logo, sugere-se que este seja complementado com unidades de funcionamento aeróbio nas câmaras que se encontram vazias na unidade de filtração.
O potencial de conservação de água do sistema em estudo, considerando o consumo médio de 16,61 $\mathrm{m}^{3} / \mathrm{mês}$, geraria uma economia de até $35 \%$ no custo mensal, se toda água de reúso gerada $\left(5,1 \mathrm{~m}^{3}\right)$, fosse reaproveitada. Todavia, os custos na implantação e operação do sistema ressaltam que este requer um tempo de funcionamento longo, de aproximadamente 38 anos, para que a economia realmente passe a ser significativa. Ressalta-se que para sistemas com capacidade de produção de água de reúso e demanda superiores geram retorno em períodos menores, visto que quanto maior a demanda por água de reúso, teoricamente, menor o "payback".

O custo para monitoramento da qualidade da água tratada pode inviabilizar o sistema, em se tratando de um sistema de pequeno porte. Destaca-se, também, que a área irrigada com água de reúso não foi afetada negativamente, havendo um melhor desenvolvimento das plantas.

\section{REFERÊNCIAS BIBLIOGRÁFICAS}

AISSE, M. M. et al. Avaliação do sistema reator UASB e filtro biológico para o tratamento de esgoto sanitário. Póstratamento de Efluentes de Reatores Anaeróbios - Coletânea de Artigos Técnicos. Vol. II - Rio de Janeiro/RJ: PROSAB/FINEP, 2001, 111-118 p.

ASSOCIAÇÃO BRASILEIRA DE NORMAS TÉCNICAS, NBR 13292: Solo - Determinação do coeficiente de permeabilidade de solos granulares e de carga constante. Rio de Janeiro, 1995.

NBR 13969: Tanques sépticos - Unidades de tratamento complementar e disposição final dos efluentes líquidos - Projeto, construção e operação. Rio de Janeiro, 1997.

ÁVILA, R. O. Avaliação do desempenho de sistemas tanque séptico-filtro anaeróbio com diferentes tipos de meio suporte. Tese (Mestrado em Ciências em Engenharia Civil) Universidade Federal do Rio de Janeiro, COPPE. Rio de Janeiro, RJ, 2005, $166 \mathrm{p}$.

BELLAMY, W. D. et al. Slow sand filtration: influences of selected process variables. Journal AWWA, Vol. 77, n. 12, 1985, 62-66 p.

BRITO, L. L. A. et al. Amadurecimento de filtros lentos de areia e remoção de microrganismos indicadores de qualidade da água ao longo da profundidade do leito: uma avaliação em instalação piloto. Engenharia Ambiental e Sanitária. Vol. 10 $n^{\circ} 4$ - out/dez - Rio de Janeiro/RJ: ABES, 2005, 307-317 p.

CHERNICHARO, C. A. L. Reatores Anaeróbios. Vol. 5. Reatores Anaeróbios. Departamento de Engenharia Sanitária e Ambiental - UFMG. 1a ed. Belo Horizonte, MG, 1997, 246 p.

DI BERNARDO, L. Métodos e técnicas de tratamento de água. ABES. 1a Ed. Vols. 1 e 2. Rio de Janeiro, RJ, 1993.

FIESP - FEDERAÇÃO DAS INDÚSTRIAS DO ESTADO DE SÃO PAULO. Guia de conservação e reúso da água em edificações. São Paulo, 2005.

JORDÃO, E. P.; PESSÔA, C. A. Tratamento de esgotos domésticos. ABES. $4^{\mathrm{a}}$ ed. Rio de Janeiro, RJ, 2005, 932 p. 
OLIVEIRA, L. H. Metodologia para a implantação de programa de uso racional de água em edifício. Tese (Doutorado em Engenharia Civil) - Escola Politécnica, Universidade de São Paulo. São Paulo, SP, 1999, 344 p.

OLIVEIRA, L. H. et al. Habitação mais sustentável Levantamento do estado da arte: Água. Projeto FINEP. São Paulo, SP, 2007, 107 p.

REIS, R. P. A. et al. Concepção e avaliação de desempenho de sistema domiciliar de reúso de efluentes secundários constituído por filtração com recirculação e desinfecção por UV. In: XI Simpósio Nacional de Sistemas Prediais. Curitiba, PR, 17-19 de Junho, 2009.

SOARES, J. M. D. et al. Notas de aula - Mecânica dos solos. Departamento de Transporte, Universidade Federal de Santa Maria. Santa Maria, RS, 2006, 230 p.

SOBRINHO, A. Filtros biológicos de alta taxa. Série Apuntes Técnicos. AIDIS Argentina, Buenos Aires. 1997. 30-98 p.

USEPA - U. S. ENVIRONMENTAL PROTECTION AGENCY. Guidelines for water reuse. Office of Water, Washington, DC, 2004.

VON SPERLING, M. Princípios do tratamento biológico de águas residuárias. Vol. 1. Introdução à qualidade das águas e ao tratamento de esgotos. Departamento de Engenharia Sanitária e Ambiental - UFMG. 3a ed. Belo Horizonte, MG, 2005, $452 \mathrm{p}$. 